Andreja Urbanec

Osnovna šola Orehek

andreja.urbanec@osorehek.si
Zbornik povzetkov strokovne konference Spodbujanje učinkovitega učenja, Koper, 26. avgust 2020

Abstracts of the Professional Conference Developing Effective Learning, Koper, 26 August 2020

\section{Šolska knjižnica - gradnik medpredmetnega povezovanja}

Knjižnično-informacijska znanja v osnovni šoli že vrsto let vpeljujejo aktiven način dela s pomočjo medpredmetnega povezovanja. Tovrstna oblika pouka je vedno bolj razširjena, učenci pa z aktivnim delom širše spoznavajo določeno temo. Učitelji s pomočjo medpredmetnega povezovanja krepijo timsko sodelovanje in usklajevanje. Tokratni prispevek odseva primer prakse v osnovni šoli. $V$ blok uri se prepletajo slovenski jezik, raba knjižničnega gradiva in angleški jezik. Delo poteka $v$ treh skupinah. Osnova je slovenščina kot materinččina in narečni jezik, ki jo povežemo s tujim jezikom in z rabo slovarjev. Učna ura je v praksi zelo dobro uspela, saj so bili učenci vidno navdušeni nad različnimi oblikami dela in novimi znanji, ki so jih pridobili s pomočjo aktivnih metod dela. Tak način dela prinaša prednosti tako za učitelje kot za učence. S timskim sodelovanjem oblikujemo enotne kriterije ocenjevanja znanja, skrbno načrtujemo ter usklajujemo metode in oblike dela pri pouku, učenci pa postanejo aktivnejši, ustvarjalnejši in odgovornejši za rezultate svojega dela.

Ključne besede: medpredmetna povezava, materni jezik, tuji jezik, aktivne oblike pouka, šolska knjižnica

\section{School Library - a Place for Building Cross-Curricular Links}

Library and information technology expertise in primary schools has been promoting an active way to work through cross-curricular links. Such lessons are becoming more and more widespread, as pupils discover new topics through active work. Through cross-curricular instruction, teachers strengthen team work and collaboration. The following article demonstrates an example of practice in primary school. The double lesson that was implemented features the Slovene language, the use of library material and the English language. Work is conducted in three small groups. The lesson is based on the Slovene language as a mother tongue and vernacular, and also incorporates foreign language and the use of dictionaries. In practice, the lesson was successfully carried out, as pupils were visibly interested about various methods of work. Such work has many advantages for pupils and teachers. Team work helps us to create the same criteria for knowledge assessment. Planning and work methods are carefully prepared. Pupils become more active, creative and responsible for their work results.

Key words: cross-curricular links, mother tongue, foreign language, active forms of instruction, school library 